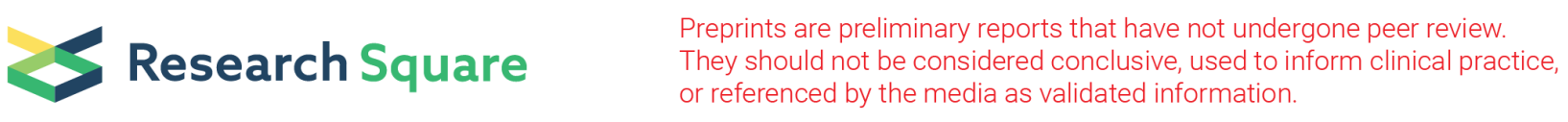

\title{
Grass-legume intercropping in integrated crop-livestock systems: a strategy to improve soil quality and soybean yield in the Brazilian Cerrado
}

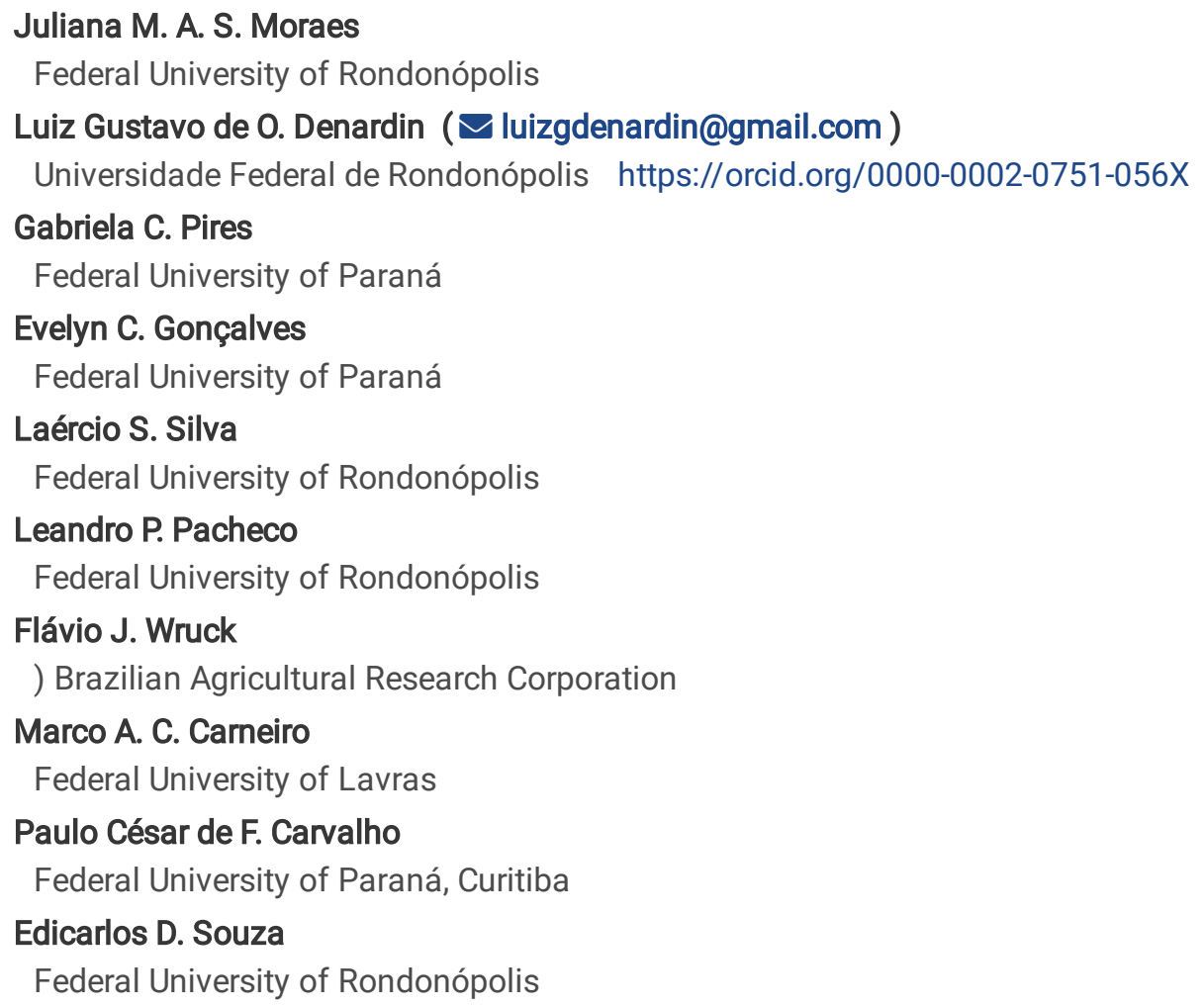

\section{Research Article}

Keywords: microbial biomass, microbial activity, enzymatic activity, soil organic matter, mixed pastures

Posted Date: September 9th, 2021

DOI: https://doi.org/10.21203/rs.3.rs-831197/v1

License: @ (i) This work is licensed under a Creative Commons Attribution 4.0 International License. Read Full License 


\section{Abstract}

\section{Aims}

The integrated crop-livestock systems (ICLS) under no-tillage improves soil fertility of the Brazilian Cerrado. We aimed to evaluate the effect of different grass-legume intercropping compared to single grass cultivation in the off-season of an ICLS on (i) soil organic carbon (C) and nitrogen (N) pools, (ii) soil microbial biomass and activity, (iii) soil enzymatic activity, and (iv) soybean grain yield in succession.

\section{Methods}

The field study was conducted in an on-farm experiment in 2016/17 and 2017/18 cropping seasons. The soybean was cultivated in the summer season, with the subsequent treatments in the off-season, using two grasses (Urochloa ruziziensis and $U$. brizantha), single or intercropped with Cowpea (Vigna unguiculata) or Pigeon pea (Cajanus cajan). We evaluated soil organic $\mathrm{C}$ and $\mathrm{N}$ pools, microbial biomass and activity, enzyme activity, and soybean yield.

\section{Results}

Cowpea intercropping yielded $24 \%$ more soybeans than grasses single cropped. There was a higher microbial biomass and activity, and enzymatic activity in the soil under grass-legume intercropping. In addition to the lower basal respiration and microbial metabolic quotient $\left(q \mathrm{CO}_{2}\right)$, the greater microbial quotient $(q \mathrm{MIC})$ and microbial biomass $\mathrm{C}$ indicate a higher soil microbial $\mathrm{C}$ utilization efficiency under grass-legume intercropping. The soil total organic $\mathrm{C}$ and $\mathrm{N}$ stocks increased under Pigeon pea intercropping by $16 \%$ and $27 \%$, respectively, compared to single grasses.

\section{Conclusions}

Grass-legume intercropping in the pasture phase of ICLS is an additional tool to maximize soybean yields in the short term. The intercropping effects on soybean yield were directly related to soil quality improvements through soil biological and biochemical properties.

\section{Introduction}

The Brazilian Cerrado is the second largest biome in Brazil extending over 200 million ha $^{-1}$ (Batlle-Bayer et al. 2010) and is the most important agricultural frontier in the world (PROBIO 2004). Represented by wet summers and dry winters (low and irregular rainfall), this region have large risks in growing a successful dry-season crop (thereafter named off-season) (Borghi et al. 2013). Likewise, this region has reported problems due to lack of crop diversification (Petter et al. 2017; Trevisan et al. 2017), leading to decreased soil fertility and crop yield. This results in natural resources degradation and higher production costs (Freddi et al. 2017; Luciano et al. 2012; Tavanti et al. 2019).

Integrated agricultural production, such as ICLS, is a feasible option to increase food production during times of irregular rain and reduced pasture availability (Almeida et al. 2021; Moraes et al. 2019b; Soares et al. 2020), such as the Cerrado region. According to Salton et al. (2014), Sarto et al. (2020) and Reis et al. (2021), the ICLS adoption helps to improve soil quality and brings sustainability to the production system of the Brazilian Cerrado. The benefits of ICLS include increased soil fertility due to soil organic matter accumulation (Alves et al. 2020), improved nutrient cycling (Assmann et al. 2017; Carvalho et al. 2010), and increased fertilizer use efficiency (Denardin et al. 2020). The rotation of cash crops with livestock under no-till can also help to break pest, disease, and weed cycles, thus reducing production costs, increasing economic and environmental outcomes (Carvalho et al. 2021; Farias et al. 2020; Lazzarotto et al. 2009; Martha Junior et al. 2011).

Many studies indicate that ICLS under no-till are beneficial for sustainably intensifying crop production in tropical regions (Crusciol et al. 2021; Mateus et al. 2020; Moraes et al. 2019b; Salton et al. 2014). In Cerrado region, adoption of ICLS alone increases soil 
organic C content, compared to using pasture as a cover crop (Gazolla et al. 2015; Sant-anna et al. 2017; Sarto et al. 2020). Current ICLS typically use a single grass species (e.g. Urochloa brizantha or U. ruziziensis) in the pasture phase (Carvalho et al. 2011; Rocha et al. 2020). However, diversifying botanical composition can lead to different inputs of residues and exudation of organic compounds (Chávez et al. 2011; Moujahid et al. 2017), activating the soil microbiota and nutrient cycling and improving soil fertility (Costa et al. 2015; Hungria et al. 2009; Martins et al. 2017). One way to increase botanical diversity is to intercrop the grass ley with a legume (Mead and Willey 1980). This leads to increased soil organic C and N (Louarn et al. 2015; Nascente and Stone 2018), mainly through increases in the labile $\mathrm{C}$ and N pools (Ball et al. 2020; Hungria et al. 2009; Laroca et al. 2018; Schipanski and Drinkwater 2012).

In addition to soil organic $\mathrm{C}$ and $\mathrm{N}$ pools, soil microbial biomass and activity are good short term indicators of anthropogenic interventions, and can be used to evaluate soil quality under different soil managements (Bending et al. 2000; Feng et al. 2021; Lopes et al. 2013; Zhao et al. 2015). Soil enzymatic activity is also being widely used as they allow of the measuring of the catabolism of organic and mineral components in the soil, because they are highly sensitive to provide information about changes in key soil functions (Bandick and Dick 1999; Sekaran et al. 2020; Verstraete and Voets 1977). In this regard, the basal respiration rate, $q \mathrm{CO}_{2}$, and the $q \mathrm{MIC}$, also provide measures of the activity of microbial communities (Anderson and Domsch 1978; Wardle and Ghani 1995).

In general, an increase in the total enzymatic activity of soil is observed under grass-legume intercropping at the pasture phase (Curtright and Tiemann 2021; Laroca et al. 2018), mainly due to an increase in soil microbial community and activity (Mwakilili et al. 2021; Moraes et al. 2019; Pires et al. 2021; Zhao et al. 2015). Leguminous plants are capable of producing a wide variety of metabolic agents, such as flavonoids and strigolactones, increasing microbial biomass (Chang et al. 2017; Pires et al. 2021). According to Zhao et al. (2015), the fungal biomass is significantly greater under grass-legume intercropping than under grass monoculture. Likewise, the grass-legume intercropping positively affects the activity and diversity of arbuscular mycorrhizal fungi species (Pires et al. 2021).

The ICLS adoption with grass-legume intercropping can improve microbial biomass $\mathrm{C}$ and $\mathrm{N}$ (Dhakal and Islam 2018; Hurisso et al. 2013) and soil organic $C$ and N stocks (Frasier et al. 2016; Li et al. 2016). Hence, intercropping systems may increase pasture production during the off-season and grain crop yields in succession (Dhakal and Islam 2018; Laroca et al. 2018; Mateus et al. 2020; Pires et al. 2021). From this, it is expected that grass-legume intercropping in ICLS will lead to a higher $\mathrm{N}$ availability, and greater microbial and enzymatic activity and soil organic $\mathrm{C}$ and $\mathrm{N}$ contents. As a consequence of the soil quality improvements, it is expected that grass-legume intercropping would increase grain yield of soybean in succession. The objective of this study was to evaluate the effect of different grass-legume intercropping compared to single grass cultivation on (i) soil organic $\mathrm{C}$ and $\mathrm{N}$ pools, (ii) soil microbial biomass and activity, (iii) soil enzymatic activity, and (iv) soybean grain yield in succession under ICLS in the Brazilian Cerrado region.

\section{Material And Methods}

\subsection{Site description and historical characterization of the experimental area}

A field experiment was conducted during the 2016/2017 and 2017/2018 soybean cropping seasons at "Gravataí Farm", Itiquira

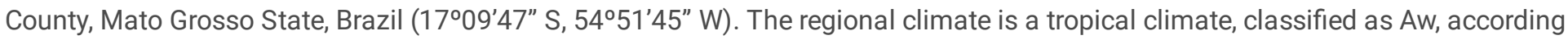
to Koeppen, with rainy periods from October to April and dry periods from May to September. The local annual average temperature was $24.8^{\circ} \mathrm{C}$, and the annual cumulative rainfall was $1350 \mathrm{~mm}$ (Supplementary Figure S1). The soil is classified as Oxisol (Soil Survey Staff 2000$)$, with a clay texture $(48,12$, and $40 \%$ of clay, silt, and sand, respectively).

Prior to the experiment, the field was used for no-till soybean (Glycine max) - maize (Zea mays) rotations from 1993 to 2004 ; a cotton (Gossypium hirsutum) monoculture from 2005 to 2011; and a soybean-pasture (Urochloa ruziziensis) ley rotation from 2012 to 2015. The experiment began in 2016 and was conducted during the 2016/17 and 2017/18 cropping seasons.

Immediately before the installation of the experiment, the soil was sampled in the $0-10 \mathrm{~cm}$ layer and analyzed for chemical and physical characterization, being: $\mathrm{pH}-\mathrm{H}_{2} \mathrm{O}$ (1:1 soil/water ratio) of 5.3; exchangeable aluminum, calcium, and magnesium ( $\mathrm{KCl} 1 \mathrm{~mol}$ 
$\mathrm{L}^{-1}$ ) of $0.2,2.7$, and $0.9 \mathrm{cmol}_{\mathrm{C}} \mathrm{dm}^{-3}$, respectively; available phosphorus and potassium (Mehlich 1) of 28.2 and $91.0 \mathrm{mg} \mathrm{dm}^{-3}$, respectively; cation exchange capacity at $\mathrm{pH} 7.0$ of $8.8 \mathrm{cmol}_{\mathrm{C}} \mathrm{dm}^{-3}$; base saturation of $43.4 \%$; and soil bulk density (pipette method) of $1.38 \mathrm{~kg} \mathrm{dm}^{-3}$.

Soybeans were sown in October and harvested 110 days after sowing. Soybean sowing was carried out with a spacing of $45 \mathrm{~cm}$ between rows and 17 plants per meter, using TMG 1174 RR cultivar. The annual fertilization in the soybean sowing was $50 \mathrm{~kg} \mathrm{ha}^{-1}$ of monoammonium phosphate ( $12 \%$ of $\mathrm{N} ; 52 \%$ of $\left.\mathrm{P}_{2} \mathrm{O}_{5}\right), 120 \mathrm{~kg} \mathrm{ha}^{-1}$ of potassium chloride $\left(58 \%\right.$ of $\left.\mathrm{K}_{2} \mathrm{O}\right), 290 \mathrm{~kg} \mathrm{ha}^{-1}$ of simple superphosphate $\left(18 \%\right.$ of $\mathrm{P}_{2} \mathrm{O}_{5}$ ), and $75 \mathrm{~kg} \mathrm{ha}^{-1}$ of elemental sulfur. For the desiccation, glyphosate ( $\mathrm{N}$-(phosphonomethyl) glycine) was used, divided into two sequential applications.

\subsection{Experimental design and treatments}

The experiment started after the soybean harvest in the 2015/2016 cropping season, with direct sowing of grasses in the pasture phase. The experiment, with a total area of approximately $60 \mathrm{ha}$, was divided into 18 plots, with an average plot area of $3.5 \mathrm{ha}$. The experiment was designed as randomized blocks, with three repetitions and subdivided plots. The main factors were two types of grasses ( $U$. ruziziensis and $U$. brizantha cv. BRS Paiaguás), with subdivided plots representing the intercrop with legumes (Cowpea [Vigna unguiculata] cv. BRS Tumucumaque, or Pigeon pea [Cajanus cajan] cv. BRS Mandarin) and single grasses.

The pasture sowing was performed with seed rates of 4.0 and $21.0 \mathrm{~kg} \mathrm{ha}^{-1}$ of viable pure seeds, for grasses and legumes, respectively. Pasture sowing was performed after soybean harvest (at the beginning of February of each year). Grasses were sown by broad casting and for the intercrop with legumes was used precision seeders with a $45 \mathrm{~cm}$ spacing.

Yearling Nelore females (Bos taurus indicus) weighing around $235 \mathrm{~kg}$ were used for grazing. A variable number of cattle were used following the put-and-take technique (Mott and Lucas 1952) to maintain the recommended grazing intensities. Average adopted pasture height was $60 \mathrm{~cm}$, and average stocking rate in the different treatments were (in kg live weight ha-1): 1,170 in U. ruziziensis + Cowpea; 855 in U. ruziziensis + Pigeon pea; 675 in single U. ruziziensis, 1,665 in U. brizantha + Cowpea; 1,260 U. brizantha + Pigeon Pea; and 945 in single $U$. brizantha. The grazing period occurred from May to the end of August. Cattle's feeding was forage-based with only mineral salt being provided.

\subsection{Soil and plant analyses}

In March 2018, soil samples were collected after soybean harvesting. Five samples in representative areas of each plot were randomly collected in the $0-10 \mathrm{~cm}$ soil layer. Each sample was composed of five sub-samples collected from the nearby area. The soil samples were stored in plastic bags and transported to the laboratory. Part of the samples for the chemical analyses was dried in a forced-air circulation oven at $50^{\circ} \mathrm{C}$, ground, and sieved through 2-mm mesh. Another part was stored in a refrigerated room and kept refrigerated $\left(4^{\circ} \mathrm{C}\right)$ for soil microbial biomass and enzymatic activity evaluation.

\subsubsection{Soil carbon and nitrogen stocks}

Soil $\mathrm{C}$ and $\mathrm{N}$ contents were analysed by dry combustion in a Fisher Scientific FlashEA $\circledast$. Soil bulk density was measured using the volumetric ring method (Blake and Hartge 1986), in the $0-10 \mathrm{~cm}$ soil layer. Then, the $C$ and $\mathrm{N}$ stocks in the $0-10 \mathrm{~cm}$ soil layer were calculated by equivalent soil mass method (Ellert and Bettany 1995). The soil used as the reference was the one with the greatest mass.

\subsubsection{Soil microbiological and biochemical analysis}

The microbiological and biochemical determinations were performed in fresh soil samples, preserving the soil field moisture. Soil C and $\mathrm{N}$ microbial biomass contents were determined according to the fumigation-extraction method (Brookes et al. 1985; Vance et al. 1987), with a soil extractor ratio of 1:2.5 (Tate et al. 1988) and a correction factor of 0.33 and 0.54 for $C$ and $N$, respectively (Brookes et al. 1985). Extraction in fumigated and non-fumigated samples was performed with potassium sulfate $0.5 \mathrm{~mol} \mathrm{~L}^{-1}$. The $\mathrm{C}$ and $\mathrm{N}$ were measured according to Tedesco et al. (1995). Basal respiration was determined according to the methodology proposed by Jenkinson and Powlson (1976). The $q \mathrm{CO}_{2}$ was calculated by dividing the basal respiration ( $\mathrm{mg} \mathrm{CO} \mathrm{CO}^{2} \mathrm{~kg}^{-1}$ dry soil day ${ }^{-1}$ ), by the 
microbial C content (Anderson and Domsch 1993). The qMIC was calculated as the ratio of microbial C by total soil organic C (Sparling 1992).

The hydrolysis of fluorescein diacetate (FDA) was determined by the method proposed by Dick et al. (1996). Urease enzyme activity assayed by the method of Tabatabai and Bremner (1972). $\beta$-Glucosidase enzyme activity was assayed by the method of Eivazi and Tabatabai (1988). Acid phosphatase was quantified following the method of Dick et al. (1996). Arylsulfatase activity was obtained by the method proposed by Tabatabai (1994).

\subsubsection{Plant analysis}

In 2016 and 2017 growing seasons, the pasture shoot biomass was sampled before the start of grazing, according to the methodology proposed by Crusciol et al. (2005). Six random points were collected per plot, using a metallic square with an area of $0.25 \mathrm{~m}^{2}$. The samples were dried in an oven to determine the dry matter weight. In the 2016/2017 and 2017/2018 cropping seasons, soybean yield was evaluated by collecting soybean in the entire plot 110 days after sowing. Harvesting was performed by an automated harvester. The samples were threshed, cleaned, and weighed. The grain moisture was determined and adjusted to $130 \mathrm{~g}$ $\mathrm{kg}^{-1}$.

\subsubsection{Statistical analyses}

Analyses were performed using the Sisvar (version 5.6) and SigmaPlot (version 10.0) statistical software's, and the data were assessed using analysis of variance (ANOVA). The model considered the two types of grasses as the main factors, with the intercrops as the subdivided plots. Model residual assumptions were checked with the Shapiro-Wilk normality test and Levene's homogeneity of variance test. When a factor was deemed significant in the ANOVA, least squared means were calculated and compared using Tukey's adjustment. All the tests were performed at a significance level of alpha $=0.05$.

Person correlation was done (SigmaPlot for Windows v. 13.0, Systat Software, Inc., San Jose, CA) using all the data, and models were assessed using both their statistical significance and coefficient of correlation ( $r$ ). Principal component analysis (PCA) was conducted by the Statistica 7.0 program, to discriminate the indicator attributes associated to productivity which best characterize the productive potential of each treatment in two-dimensional plans. The principal components were generated from the eigenvalues of the covariance matrix obtained from the original variables. Only eigenvalues greater than one were considered.

\section{Results}

\subsection{Soil carbon and nitrogen pools}

The total organic $\mathrm{C}$ and $\mathrm{N}$ stocks were affected by both the grasses and the legumes intercropping (Table 1). The use of $U$. ruziziensis increased the total organic $\mathrm{C}$ stock in $0.79 \mathrm{Mg} \mathrm{ha}^{-1}$ compared to $U$. brizantha. On the other hand, the stock of total organic $\mathrm{N}$ was $1.47 \mathrm{Mg} \mathrm{ha}^{-1}$ higher when $U$. brizantha was used. The total organic $\mathrm{C}$ stock on Pigeon pea intercropping was $14.9 \%$ and $16.0 \%$ higher than Cowpea intercropping and single grass cultivation, respectively (Table 1). The intercropping with Pigeon Pea also increased the total organic $\mathrm{N}$ stock by $27.1 \%$ compared to the single grass cultivation, with intermediate $\mathrm{N}$ stock in intercropping with Cowpea $\left(6.17 \mathrm{Mg} \mathrm{ha}^{-1}\right)$. 
Table 1

Total organic carbon and nitrogen stocks, particulate organic carbon and nitrogen stocks two years after the adoption (March 2018) of an integrated crop-livestock system under no-tillage with intercrops at the pasture stage

\begin{tabular}{|c|c|c|c|c|}
\hline \multirow[t]{2}{*}{ Grasses } & \multicolumn{3}{|c|}{ Intercrops } & \multirow[t]{2}{*}{ Average } \\
\hline & Cowpea & Pigeon Pea & Single & \\
\hline & \multicolumn{4}{|c|}{ Total organic carbon stock (Mg ha-1) } \\
\hline U. Ruziziensis & 32.7 & 36.4 & 32.9 & $34.00 \mathrm{~A}$ \\
\hline U. brizantha & 31.5 & 37.4 & 30.7 & $33.21 \mathrm{~B}$ \\
\hline \multirow[t]{2}{*}{ Average } & $32.12 \mathrm{~b}$ & $36.90 \mathrm{a}$ & $31.80 \mathrm{~b}$ & \\
\hline & \multicolumn{4}{|c|}{ Total organic nitrogen stock $\left(\mathrm{Mg} \mathrm{ha}^{-1}\right)$} \\
\hline U. Ruziziensis & 5.23 & 5.87 & 4.60 & $5.23 \mathrm{~B}$ \\
\hline U. brizantha & 7.10 & 7.27 & 5.73 & $6.70 \mathrm{~A}$ \\
\hline Average & $6.17 \mathrm{ab}$ & $6.57 \mathrm{a}$ & $5.17 \mathrm{~b}$ & \\
\hline \multicolumn{5}{|c|}{ Particulate organic carbon stock (Mg ha-1) } \\
\hline U. Ruziziensis & $2.60 \mathrm{Ab}$ & $4.00 \mathrm{Aa}$ & $1.53 \mathrm{Bc}$ & 2.71 \\
\hline U. brizantha & 2.47 Ans & $3.10 \mathrm{~B}$ & $2.40 \mathrm{~A}$ & 2.65 \\
\hline Average & 2.53 & 3.55 & 1.97 & \\
\hline \multicolumn{5}{|c|}{ Particulate organic nitrogen stock $\left(\mathrm{Mg} \mathrm{ha}^{-1}\right)$} \\
\hline U. Ruziziensis & 0.30 & 0.50 & 0.30 & $0.37 \mathrm{~B}$ \\
\hline U. brizantha & 0.53 & 0.60 & 0.73 & $0.62 \mathrm{~A}$ \\
\hline Average & $0.42 \mathrm{~ns}$ & 0.55 & 0.52 & \\
\hline
\end{tabular}

Whereas particulate organic $C$ was $29.0 \%$ higher in U. ruziziensis when intercropped with Pigeon Pea, when the grass was singlecropped the particulate organic $\mathrm{C}$ was $56.9 \%$ higher using $U$. brizantha (Table 1 ). In Cowpea intercropping the particulate organic $\mathrm{C}$ was independent on the grasses. Using $U$. Ruziziensis, the Pigeon pea intercropping had the highest particulate organic $\mathrm{C}(4.0 \mathrm{Mg}$ $\left.\mathrm{ha}^{-1}\right)$, followed by Cowpea intercropping $\left(2.6 \mathrm{Mg} \mathrm{ha}^{-1}\right)$ and the single grass cultivation $\left(1.5 \mathrm{Mg} \mathrm{ha}^{-1}\right)$. However, using $U$. brizantha the particulate organic $\mathrm{C}$ was independent on legumes intercropping. Particulate organic $\mathrm{N}$ was $67.6 \%$ higher using $U$. brizantha grass compared to U. ruziziensis, and similar among legumes intercropping (Table 1).

Regarding microbial biomass $\mathrm{C}$ and $\mathrm{N}$, the grasses effect was different among the legumes intercropping. When intercropped with Cowpea and Pigeon pea the $U$. brizantha had a microbial biomass $C 17.1 \%$ and $55.2 \%$, respectively higher than $U$. ruziziensis (Table 2). On the other hand, when single-cropped $U$. ruziziensis had $51.7 \%$ higher microbial biomass $C$ than $U$. brizantha. Regardless of the grasses used, soil microbial biomass $\mathrm{C}$ was higher when intercropped with Cowpea. However, when using $U$. ruziziensis the microbial biomass $\mathrm{C}$ was similar between the other intercropping, and under $U$. brizantha the Pigeon pea had $86.4 \%$ more microbial biomass $\mathrm{C}$ than the single crop (Table 2). 
Table 2

Soil microbial biomass carbon and nitrogen, basal respiration, metabolic quotient $\left(q \mathrm{CO}_{2}\right)$, and microbial quotient ( $q \mathrm{MIC}$ ) two years after the adoption (March 2018) of an integrated crop-livestock system under no-tillage and different grasses and intercrops at the pasture stage

\begin{tabular}{|c|c|c|c|}
\hline \multirow[t]{2}{*}{ Grasses } & \multicolumn{3}{|l|}{ Intercrops } \\
\hline & Cowpea & Pigeon Pea & Single \\
\hline & \multicolumn{3}{|c|}{ Microbial biomass carbon ( $\mathrm{mg} \mathrm{kg}^{-1}$ soil) } \\
\hline U. Ruziziensis & $705.7 \mathrm{Ba}$ & $352.3 \mathrm{Bb}$ & $445.0 \mathrm{Ab}$ \\
\hline \multirow[t]{2}{*}{ U. brizantha } & $826.3 \mathrm{Aa}$ & $546.7 \mathrm{Ab}$ & $293.3 \mathrm{Bc}$ \\
\hline & \multicolumn{3}{|c|}{ Microbial biomass nitrogen ( $\mathrm{mg} \mathrm{kg}^{-1}$ soil) } \\
\hline U. Ruziziensis & $51.7 \mathrm{Aa}$ & $50.0 \mathrm{Aa}$ & $16.7 \mathrm{Ab}$ \\
\hline \multirow[t]{2}{*}{ U. brizantha } & $54.0 \mathrm{Aa}$ & $40.7 \mathrm{Bb}$ & $14.7 \mathrm{Ac}$ \\
\hline & \multicolumn{3}{|c|}{ Basal respiration (mg C-CO $\mathrm{kg}^{-1}$ soil $\mathrm{h}^{-1}$ ) } \\
\hline U. Ruziziensis & $6.46 \mathrm{Ac}$ & $12.53 \mathrm{Ab}$ & $17.20 \mathrm{Aa}$ \\
\hline \multirow[t]{2}{*}{ U. brizantha } & $5.30 \mathrm{Ab}$ & $3.33 \mathrm{Bb}$ & $8.03 \mathrm{Ba}$ \\
\hline & \multicolumn{3}{|c|}{$\mathrm{qCO}_{2}\left(\left(\mathrm{mg} \mathrm{C}^{-\mathrm{CO}_{2} \mathrm{mg}^{-1} \mathrm{C}-\mathrm{MB} \mathrm{h}} \mathrm{h}^{-1}\right) \times 10^{-3}\right)$} \\
\hline U. Ruziziensis & $12.67 \mathrm{Ac}$ & $26.00 \mathrm{Ab}$ & $104.33 \mathrm{Aa}$ \\
\hline \multirow[t]{2}{*}{ U. brizantha } & $10.33 \mathrm{Ab}$ & 8.67 Bb & $57.67 \mathrm{Ba}$ \\
\hline & \multicolumn{3}{|l|}{ qMIC (\%) } \\
\hline U. Ruziziensis & $2.83 \mathrm{Aa}$ & $1.37 \mathrm{Ab}$ & $1.76 \mathrm{Ab}$ \\
\hline U. brizantha & $3.40 \mathrm{Aa}$ & $1.93 \mathrm{Ab}$ & $1.20 \mathrm{Ab}$ \\
\hline
\end{tabular}

The microbial biomass $\mathrm{N}$ was $22.8 \%$ higher in $U$. ruziziensis only when intercropped with Pigeon pea, and similar in the other intercropping (Table 2). In both grasses the legume intercropping had higher microbial biomass $\mathrm{N}$ than the single crop. However, using $U$. ruziziensis the microbial biomass $\mathrm{N}$ was similar between intercropping and under $U$. brizantha the Cowpea intercropping had $32.7 \%$ more microbial biomass $\mathrm{N}$ than the Pigeon pea intercropping (Table 2).

\subsection{Microbial and enzymatic activity}

The basal respiration and the $q \mathrm{CO}_{2}$ had significant interaction between grasses and legumes intercrops (Table 2). The basal respiration and the $\mathrm{qCO}_{2}$ indicated that using $U$. ruziziensis single-cropped leads to higher biological activity. The lowest basal respiration and $q \mathrm{CO}_{2}$ were found under $U$. brizantha intercropped with pigeon pea. Both basal respiration and $q \mathrm{CO}_{2}$ were higher in single grass than in intercrops, and the use of $U$. brizantha decreased the basal respiration and the $q \mathrm{CO}_{2}$ by $53 \%$ and $45 \%$, respectively, compared to $U$. ruziziensis (Table 2). The use of Pigeon pea intercropped with $U$. ruziziensis increased the basal respiration and the $q \mathrm{CO}_{2}$ by $94 \%$ and $106 \%$, respectively, compared to Cowpea intercropping. However, using $U$. brizantha both the basal respiration and the $q \mathrm{CO}_{2}$ were similar between the intercropped legumes. The $q \mathrm{MIC}$ was similar between grasses, but it was $88 \%$ and $113 \%$ higher under Cowpea intercropping, compared to Pigeon pea intercropping and single cropping, respectively (Table 2).

Regardless of the intercropping, the $\beta$-glucosidase activity was higher with $U$. brizantha. Similarly, in both grasses the $\beta$-glucosidase activity was $31 \%$ and $65 \%$ higher when intercropped with Pigeon pea, compared to Cowpea and single cropping, respectively (Fig. 1A). The FDA release was similar between the grasses intercropped with Cowpea, but $77 \%$ and $98 \%$ higher in $U$. ruziziensis 
compared to $U$. brizantha, when intercropped with Pigeon pea and single-cropped, respectively (Fig. 1B). Using U. ruziziensis, the FDA release was higher in Pigeon pea intercropping than in single-cropped, followed by Cowpea intercropping. However, the intercropping with both legumes were superior to single cropped of $U$. brizantha (Fig. 1B).

The arylsulfatase activity was higher under $U$. ruziziensis than $U$. brizantha, in all the intercropping (Fig. 1C). Under $U$. ruziziensis the Pigeon pea intercropping had higher arylsulfatase activity than the single cropping, with an intermediate level in the Cowpea intercropping. On the other hand, under $U$. brizantha, the Pigeon pea intercropping had $62 \%$ and $53 \%$ lower arylsulfatase activity than Cowpea intercropping and single cropping, respectively (Fig. 1C). The activity of acid phosphatase and urease were independent of the grasses and legume intercrops (Figs. 1D and 1E).

\subsection{Pasture and soybean yield}

The pasture shoot biomass production of $U$. ruziziensis was higher than that of $U$. brizantha, both intercropped with Cowpea and single-cropped (26\% and $16 \%$, respectively) (Fig. 2). The grasses yielded similar amounts of shoot biomass when intercropped with Pigeon pea (5.3 $\mathrm{Mg} \mathrm{ha}^{-1}$ ). Similarly, whereas $U$. ruziziensis yielded more biomass when intercropped with Cowpea or single cropped, U. brizantha had similar shoot biomass productions among the intercrops (Fig. 2).

The highest soybean yield was found under $U$. brizantha intercropped with Cowpea $\left(3.9 \mathrm{Mg} \mathrm{ha}^{-1}\right)$, on average for both cropping seasons (Fig. 3A). Soybean yielded $5 \%$ more after U. brizantha + Cowpea than after U. ruziziensis + Cowpea. On the other hand, when intercropped with Pigeon pea or single-cropped, soybean yields were $9 \%$ and $8 \%$ higher, respectively, using U. ruziziensis compared to $U$. brizantha (Fig. 3A). Regardless of the grasses evaluated, Cowpea intercropping yielded $18 \%$ and $24 \%$ more soybeans than Pigeon pea intercropping and single-cropped, respectively. Regarding the cropping seasons, soybeans yielded $20 \%$ more in 2017/2018 crop than in 2016/2017 (3.1 Mg ha-1) (Fig. 3B).

\subsection{Relationship among the variables}

Positive and significant correlation was found between soybean yield and microbial biomass $\mathrm{C}(\mathrm{r}=0.74)$, microbial biomass $\mathrm{N}(\mathrm{r}=$ $0.50)$ and $q \mathrm{MIC}(\mathrm{r}=0.70)$ and inversely proportional to $q \mathrm{CO}_{2}(r=-0.40)$ (Table 3$)$. In addition to microbial biomass $\mathrm{N}(\mathrm{r}=0.60)$, basal respiration $(r=-0.50), q \mathrm{CO}_{2}(r=-0.53)$ and $q \mathrm{MIC}(r=0.96)$, microbial biomass $C$ was also correlated with urease activity $(r=0.39)$. Microbial biomass $\mathrm{N}$ had a correlation with basal respiration $(r=-0.47), q \mathrm{CO}_{2}(r=-0.84), q \mathrm{MIC}(r=0.63)$, acid phosphatase $(r=0.60)$, and urease $(r=0.60)$ (Table 3). In addition to acid phosphatase $(r=-0.56)$ and urease $(r=-0.46), q \mathrm{CO}_{2}$ correlated with $\beta$-glucosidase activity $(r=-0.68)$. The $q \mathrm{MIC}$ correlated only with urease activity $(r=0.42)$. 
Table 3

Pearson correlation coefficients among soil attributes in an integrated crop-livestock system under no-tillage with intercrop at the pasture stage

\begin{tabular}{|c|c|c|c|c|c|c|c|c|c|c|c|c|}
\hline & TOC & TN & MBC & MBN & BR & $q \mathrm{CO}_{2}$ & qMIC & $\beta$ & $\begin{array}{l}\text { A- } \\
\text { Phos }\end{array}$ & Aril & Urease & FDA \\
\hline $\mathrm{TN}$ & $0.36^{\mathrm{ns}}$ & & & & & & & & & & & \\
\hline MBC & $-0.10^{\mathrm{ns}}$ & $0.34^{\mathrm{ns}}$ & & & & & & & & & & \\
\hline MBN & $0.22^{\mathrm{ns}}$ & $0.35^{\mathrm{ns}}$ & $0.65^{\star}$ & & & & & & & & & \\
\hline BR & $-0.12^{\text {ns }}$ & $-0.70 *$ & $-0.50^{\star}$ & $-0.47^{\star}$ & & & & & & & & \\
\hline $\mathrm{qCO}_{2}$ & $-0.26^{\mathrm{ns}}$ & $-0.64^{\star}$ & $-0.53^{\star}$ & $-0.84^{\star}$ & $0.83^{*}$ & & & & & & & \\
\hline qMIC & $-0.33^{n s}$ & $0.20^{\mathrm{ns}}$ & $0.96^{*}$ & $0.63^{*}$ & $-0.42^{\star}$ & $-0.47^{\star}$ & & & & & & \\
\hline$\beta$ & $0.20^{\mathrm{ns}}$ & $0.70 *$ & $0.06^{\mathrm{ns}}$ & $0.38^{\text {ns }}$ & $-0.68 *$ & $-0.68^{*}$ & $0.02^{\mathrm{ns}}$ & & & & & \\
\hline $\begin{array}{l}\text { A- } \\
\text { Phos }\end{array}$ & $0.19^{\mathrm{ns}}$ & $0.21^{\mathrm{ns}}$ & $0.33^{\mathrm{ns}}$ & $0.60 *$ & $-0.37^{\mathrm{ns}}$ & $-0.56^{\star}$ & $0.29^{\mathrm{ns}}$ & $0.36^{\mathrm{ns}}$ & & & & \\
\hline Aril & $-0.02^{\text {ns }}$ & $-0.48^{\star}$ & $-0.01^{\mathrm{ns}}$ & $0.25^{\mathrm{ns}}$ & $0.51^{*}$ & $0.12^{\mathrm{ns}}$ & $0.03^{\mathrm{ns}}$ & $-0.46^{\star}$ & $0.60 *$ & & & \\
\hline Urease & $0.03^{\mathrm{ns}}$ & $0.51 *$ & $0.39 *$ & $0.60 *$ & $-0.46^{*}$ & $-0.63^{\star}$ & $0.42^{\star}$ & $0.64^{\star}$ & $-0.09^{n s}$ & $-0.09^{n s}$ & & \\
\hline FDA & $0.20^{\mathrm{ns}}$ & $-0.21^{\mathrm{ns}}$ & $-0.08^{n s}$ & $0.17^{\mathrm{ns}}$ & $0.52^{\star}$ & $0.14^{\mathrm{ns}}$ & $-0.05^{\mathrm{ns}}$ & $-0.27^{n s}$ & $0.03^{\mathrm{ns}}$ & $0.60 *$ & $0.19^{\text {ns }}$ & \\
\hline Yield & $-0.05^{\text {ns }}$ & $0.30^{\mathrm{ns}}$ & $0.74^{*}$ & $0.57 *$ & $-0.29^{n s}$ & $-0.40^{*}$ & 0.70 * & $0.12^{\mathrm{ns}}$ & $0.16^{\mathrm{ns}}$ & $0.20^{\mathrm{ns}}$ & $-0.02^{\text {ns }}$ & $-0.02^{n s}$ \\
\hline
\end{tabular}

The PCA results showed that PC1 (principal component 1) retained $40.84 \%$ and PC2 (principal component 2) retained $35.96 \%$ of data inertia, accumulating in the graph $76.8 \%$ of the information of the original matrix (Fig. 4). It is possible to verify clearly the individual effects of the treatments on the soybean yield and soil biochemical properties. From the PCA analysis it is possible to verify that the highest soybean yields were found using $U$. ruziziensis, intercropped with Cowpea or Pigeon pea. These yields were obtained by higher $q \mathrm{MIC}$ and microbial biomass $\mathrm{C}$ and $\mathrm{N}$ (Fig. 4). On the other hand, the cultivation of single $U$. brizantha has lower soybean yields.

\section{Discussion}

The grass-legume intercropping improved soil quality through soil biological and biochemical properties and increased soybean yields. The Cowpea intercropping yielded more soybeans than Pigeon pea intercropping and single-cropped. According to Laroca et al. (2018), the grass-legume intercropping with Cowpea and Pigeon pea resulted in higher soybean yields (416 and $338 \mathrm{~kg} \mathrm{ha-1}$, respectively), compared to single cropping of grasses. The higher soybean yields were associated with higher microbial biomass $\mathrm{C}$ and $\mathrm{N}$ contents, $q \mathrm{MIC}$ and lower basal respiration and $q \mathrm{CO}_{2}$ (Table 2).

The basal respiration rate and the $q \mathrm{CO}_{2}$ are variables used to measure the metabolic activity of microbial biomass in the soil. Higher $q_{\mathrm{CO}_{2}}$ values indicate $\mathrm{C}$ losses by the soil, showing stress conditions for microbiota according to the large amount of energy for its maintenance (Nunes et al. 2011). Low- $q \mathrm{CO}_{2}$ values are related to environments that are more stable or closer to their equilibrium state, as they indicate energy savings (Silva et al. 2010; Wardle and Ghani 1995). In addition, microbial biomass and qMIC are commonly used for soil quality assessment (Bastida et al. 2008; Mader et al. 2002; Salinas-García et al. 2002). Therefore, the lower basal respiration and $q \mathrm{CO}_{2}$, and the greater $q \mathrm{MIC}$ and microbial biomass $\mathrm{C}$ may indicate higher soil microbial $\mathrm{C}$ utilization efficiency (Andersen et al. 2013; Anderson and Domsch 1978; Pleisner et al. 2016) under grass-legume intercropping (Table 2). This may be 
due to the higher contribution of labile $\mathrm{C}$ and $\mathrm{N}$ (with easy oxidation) from treatments under grass-legume intercropping (Crème et al. 2016) with residue inputs with low $\mathrm{C} / \mathrm{N}$ ratio.

The residue inputs with lower $\mathrm{C} / \mathrm{N}$ ratios under grass-legume intercropping contributes to an increase in microbial biomass and activity (Leite et al. 2013; Moraes et al. 2019). This indicates a higher conversion efficiency of the $C$ and $N$ in plant residues into $C$ and $\mathrm{N}$ in microbial biomass (Balota and Chaves 2011; Spohn 2015; Veloso et al. 2019). Therefore, the grass-legume intercropping in ICLS improve soil microbial properties, which may contribute in the long run to achieve the equilibrium in the production system, since it showed low- $q \mathrm{CO}_{2}$ values, but maintained high $q \mathrm{MIC}$ values (Table 2), highlighting that the microbial biomass is not under stress and is able to use organic C efficiently (Fang et al. 2018; Hartman and Richardson 2013; Silva et al. 2010).

The microbial biomass $\mathrm{C}$ and $\mathrm{N}$ improvements under grass-legume intercropping (Table 2) were also reported by Hurisso et al. (2013) and Almeida et al. (2016). The microbial biomass $\mathrm{N}$ increments may be due to leguminous plants insertion, which favors soil $\mathrm{N}$ availability through the biological $\mathrm{N}$ fixation (Crème et al. 2016). On the other hand, in single grasses the soil microbiota consumes more $\mathrm{C}$ to maintain a lower microbial population. The greater the abundance and diversity of roots, the greater the exudation of organic compounds that will serve as a source of $C$ and energy for soil microorganisms (Chávez et al. 2011; Dhakal and Islam 2018).

The total $\mathrm{C}$ and $\mathrm{N}$ stocks also increased in the soil, mainly under Pigeon Pea intercropping, compared to single grasses (Table 1). These results demonstrate that grasses, when intercropped with legumes, promote the $\mathrm{C}$ and $\mathrm{N}$ improvements in the soil. Similar results were found by Frasier et al. (2016) and Laroca et al. (2018), who observed increases of $\mathrm{C}$ and $\mathrm{N}$ stocks in an experiment using grass-legume intercropping. Frasier et al. (2016) assigned the increase of total $\mathrm{N}$ stock to the better residue quality (lower $\mathrm{C} / \mathrm{N}$ ratio) provided by leguminous plants. Almeida et al. (2016) also documented improvements in microbial biomass $\mathrm{C}$ and $\mathrm{N}$ under grass-legume intercropping systems, which may result in higher soybean yields.

Soybean under $\mathrm{N}$-fixing bacteria inoculation does not rely to $\mathrm{N}$ fertilizer because it reduces restricts carbohydrates to nodule metabolism (Denison and Harter 1995). However, some studies have shown that $\mathrm{N}$ addition via leguminous crops may positively influence the soybean yields (Nascente and Stone 2018; Tanaka et al. 1992). The higher-N input to the soil-plant system, derived from the biological $\mathrm{N}$ fixation, may contribute to improvements of soybean yield due to the $\mathrm{N}$ source, that is gradually released through mineralization (Cicek et al. 2014; Pacheco et al. 2017). The biological $\mathrm{N}$ fixation can contribute a considerable $\mathrm{N}$ fraction in the soil, releasing to the soybean in succession, reflecting in increases in grain yield (Pacheco et al. 2017). Likewise, soybean is positively influenced by $\mathrm{N}$ fertilization in pasture grasses in advance (Costa et al. 2021).

The $\beta$-glucosidase activity was also higher under grass-legume intercropping (Fig. 1A). This enzyme acts on the hydrolysis of organic compounds and it is important in the $\mathrm{C}$ life cycle (Bowles et al. 2014). It has a direct relationship with the $\mathrm{N}$ stock in the soil (Stieven et al. 2014), which was also higher under grass-legume intercropping (Table 2). The higher FDA activity found in grasslegume intercropping treatments (Fig. 1B) corroborate the results of Ferreira et al. (2017), which found higher FDA activity in agroecological production systems with legumes compared to conventional systems using single grasses.

The acid phosphatase and urease activity were not affected by treatments (Figs. 1D and 1E). Laroca et al. (2018) found similar results where the acid phosphatase activity was not influenced by legumes or grasses, because the activity of this enzyme is more related to phosphate fertilization, which was the same in all treatments. Ye et al. (2017) reported a reduction of the acid phosphatase activity, and associated this result with the excess available phosphorous in the soil. Lanna et al. (2010) documented greater urease activity related to higher $\mathrm{N}$ content in the soil. Despite not differing significantly (Fig. 1E), same effect was found in this study, where the urease activity was correlated $\left(r=0.51^{\star}\right)$ to total $\mathrm{N}$ stocks (Table 3 ).

Regarding the arylsulfatase activity, studies conducted in Brazil indicate that the quality of residues added to the soil are more determinant in the activity of this enzyme than the quantity of residues (Balota et al. 2011), and the input of more labile organic residues helps the activity of this enzyme (Lisboa et al. 2012). In addition, the higher contents of total organic C stocks (Table 1) can provide high levels of sulfur in the form of sulfate esters which, in turn, are substrates for this enzyme (Balota et al. 2014).

In summary, legume intercrops increased microbial activity and biomass and total C and N stocks, and qMIC, and decreased basal respiration and $q \mathrm{CO}_{2}$, compared to single grasses in pasture phase. However, the adoption of ICLS under no-till using single grasses in pasture phase is already an important way to improve soil quality (Sarto et al. 2020) and grain yield, even in the short-term

Page 10/18 
(Carneiro et al. 2009). In the Brazilian Cerrado region, soil C improvements can reach $26 \mathrm{~g} \mathrm{~kg}^{-1}$ under ICLS compared to $U$. decumbens as cover crop (Gazolla et al. 2015). Alves et al. (2011), evaluating microbial properties, documented a microbial biomass C 60\% higher under ICLS compared to the native vegetation of Cerrado region. Therefore, grass-legume intercropping in the pasture phase of ICLS is an additional tool to maximize soil quality improvements and soybean yields even in the short-term.

\section{Conclusions}

Our results highlights the importance of grass-legume intercropping at the pasture stage in ICLS in the Brazilian Cerrado region. The grass-legume intercropping, mainly with Cowpea, increases the microbial biomass carbon and nitrogen and microbial quotient. On the other hand, single grasses cause stress in the microbiota by the increase of the basal respiration and metabolic quotient. In general, an increase in the total enzymatic activity of soil is observed when using grass-legume intercropping at the pasture stage, mainly with Pigeon pea. The grass-legume intercropping is an effective strategy to increase the total organic carbon and nitrogen stocks in the soil, which reflect in an increase in soybean grain yield.

\section{Declarations}

Funding: This research was funded by a grant from the Agrisus foundation (Project no. PA 1388/14). We also thank the National Council for the Development of Science and Technology (CNPq) for the grant (No: 454461/2014-3) and the Coordination for the Improvement of Higher Education Personnel (CAPES) for scholarship support

Conflicts of interest/Competing interests: The authors have no conflicts of interest to declare that are relevant to the content of this article

Availability of data and material: The datasets generated during and/or analysed during the current study are available from the corresponding author on reasonable request

Code availability: Not applicable

Ethics approval: Not applicable

Consent to participate: All authors are consenting to participate

Consent for publication: All authors consent for publication

Acknowledgements: We thank the National Council for the Development of Science and Technology (CNPq) and the Coordination for the Improvement of Higher Education Personnel (CAPES) for scholarship support. We also would like to thank for the Rede ILPF and EMBRAPA for the partial financial supports.

\section{References}

1. Almeida DO, Bayer C, Almeida HC (2016) Fauna e atributos microbiológicos de um Argissolo sob sistemas de cobertura no Sul do Brasil. Pesq Agropec Bras 51:1140-1147. http://dx.doi.org/10.1590/S0100-204X2016000900013

2. Almeida LLS, Frazão LA, Lessa TAM et al (2021) Soil carbon and nitrogen stocks and the quality of soil organic matter under silvopastoral systems in the Brazilian Cerrado. Soil Tillage Res 205:104785. https://doi.org/10.1016/j.still.2020.104785

3. Alves LA, Denardin LGO, Martins AP et al (2020) The effect of crop rotation and sheep grazing management on plant production and soil $\mathrm{C}$ and $\mathrm{N}$ stocks in a long-term integrated crop-livestock system in Southern Brazil. Soil Tillage Res 203:104678

4. Alves TDS, Campos LL, Elias Neto $\mathrm{N}$ et al (2011) Biomassa e atividade microbiana de solo sob vegetação nativa e diferentes sistemas de manejos. Acta Scientiarum Agronomy 33:341-347. https://doi.org/10.4025/actasciagron.v33i2.4841

5. Andersen R, Chapman SJ, Artz RRE (2013) Microbial communities in natural and disturbed peatlands: a review. Soil Biol Biochem 57:979-994. https://doi.org/10.1016/j.soilbio.2012.10.003

6. Anderson JPE, Domsch KH (1978) A physiological method for the quantitative measurement of microbial biomass in soils. Soil Biol Biochem 10:215-221. https://doi.org/10.1016/0038-0717(78)90099-8

Page $11 / 18$ 
7. Anderson TH, Domsch AK (1993) The metabolic quotient for CO2 (qCO2) as a specific activity parameter to assess the effects of environmental conditions, such as pH, on the microbial biomass of forest soils. Soil biology biochemistry 25:393-395. https://doi.org/10.1016/0038-0717(93)90140-7

8. Ball KR, Baldock JA, Penfold C et al (2020) Soil organic carbon and nitrogen pools are increased by mixed grass and legume cover crops in vineyard agroecosystems: Detecting short-term management effects using infrared spectroscopy. Geoderma 379:114619. https://doi.org/10.1016/j.geoderma.2020.114619

9. Balota EL, Chaves JCD (2011) Microbial activity in soil cultivated with different summer legumes in coffee crop. Brazilian Archives of Biology Technology 54:35-44. https://doi.org/10.1590/S1516-89132011000100005

10. Balota EL, Machineski O, Hamid KI et al (2014) Soil microbial properties after long-term swine slurry application to conventional and no-tillage systems in Brazil. Sci Total Environ 490:397-404. https://doi.org/10.1016/j.scitotenv.2014.05.019

11. Balota EL, Machineski O, Truber PV (2011) Soil enzyme activities under pig slurry addition and different tillage systems. Acta Scientiarum Agronomy 33:729-737. https://doi.org/10.4025/actasciagron.v33i4.9816

12. Bandick AK, Dick RP (1999) Field management effects on soil enzyme activities. Soil biology biochemistry 31:1471-1479. https://doi.org/10.1016/S0038-0717(99)00051-6

13. Bastida F, Zsolnay A, Hernández T et al (2008) Past, present and future of soil quality indices: a biological perspective. Geoderma 147:159-171. https://doi.org/ 10.1016/j.geoderma.2008.08.007

14. Bending GD, Putland C, Rayns F (2000) Changes in microbial community metabolism and labile organic matter fractions as early indicators of the impact of management on soil biological quality. Biol Fertil Soils 31:78-84

15. Blake GR, Hartge KH (1986) Bulk density. In: Klute A (ed) Methods of Soil Analysis: Part 1 Physical and Mineralogical Methods, 2nd edn. Wiley, New York, pp 363-375

16. Borghi E, Crusciol CAC, Nascente AS et al (2013) Sorghum grain yield, forage biomass production and revenue as affected by intercropping time. Eur J Agron 51:130-139. https://doi.org/10.1016/j.eja.2013.08.006

17. Bowles TM, Acosta-Martínez V, Calderón F et al (2014) Soil enzyme activities, microbial communities, and carbon and nitrogen availability in organic agroecosystems across an intensively-managed agricultural landscape. Soil Biol Biochem 68:252-262. https://doi.org/10.1016/j.soilbio.2013.10.004

18. Brookes PC, Landman A, Pruden G et al (1985) Chloroform fumigation and the release of soil nitrogen: a rapid direct extraction method to measure microbial biomass nitrogen in soil. Soil biology biochemistry 17:837-842. https://doi.org/10.1016/00380717(85)90144-0

19. Carneiro MAC, Souza EDD, Reis EFD et al (2009) Atributos físicos, químicos e biológicos de solo de cerrado sob diferentes sistemas de uso e manejo. Revista Brasileira de Ciência do solo 33:147-157. https://doi.org/10.1590/S010006832009000100016

20. Carvalho AMD, Souza LLPD, Guimarães Júnior R et al (2011) Cover plants with potential use for crop-livestock integrated systems in the Cerrado region. Pesquisa Agropecuária Brasileira 46:1200-1205. https://doi.org/10.1590/S0100204X2011001000012

21. Carvalho PCF, Anghinoni I, Moraes A et al (2010) Managing grazing animals to achieve nutrient cycling and soil improvement in no-till integrated systems. Nutr Cycl Agroecosyst 88:259-273

22. Carvalho PCF, Souza ED, Denardin LGO et al (2021) Reconnecting nature and agricultural production: mixed cropping systems as a way forward sustainable intensification. Boletim De Indústria Animal 78:1-16. https://doi.org/10.17523/bia.2021.v78.e11496

23. Chang C, Nasir F, Ma L et al (2017) Molecular communication and nutrient transfer of arbuscular mycorrhizal fungi, symbiotic nitrogen-fixing bacteria, and host plant in tripartite symbiosis. In: Legume nitrogen fixation in soils with low phosphorus availability. Springer, Cham, pp 169-183

24. Chávez LF, Escobar LF, Anghinoni I et al (2011) Diversidade metabólica e atividade microbiana no solo em sistema de integração lavoura-pecuária sob intensidades de pastejo. Pesquisa Agropecuária Brasileira 46:1254-1261. https://doi.org/10.1590/S0100-204X2011001000020

25. Cicek H, Entz MH, Martens JRT et al (2014) Productivity and nitrogen benefits of late-season legume cover crops in organic wheat production. Can J Plant Sci 94:771-783. https://doi.org/10.4141/cjps2013-130

Page $12 / 18$ 
26. Costa NR, Andreotti M, Crusciol CAC et al (2021) Soybean yield and nutrition after tropical forage grasses. Nutr Cycl Agroecosyst. https://doi.org/10.1007/s10705-021-10157-2

27. Costa NR, Andreotti M, Lopes KSM et al (2015) Atributos do solo e acúmulo de carbono na integração lavoura-pecuária em sistema plantio direto. Revista Brasileira de Ciência do Solo 39:852-863. https://doi.org/10.1590/01000683rbcs20140269

28. Crème A, Rumpel C, Gastal F et al (2016) Effects of grasses and a legume grown in monoculture or mixture on soil organic matter and phosphorus forms. Plant Soil 402:117-128. https://doi.org/10.1007/s11104-015-2740-x

29. Crusciol CA, Momesso L, Portugal JR et al (2021) Upland rice intercropped with forage grasses in an integrated crop-livestock system: Optimizing nitrogen management and food production. Field Crops Research 261:108008. https://doi.org/10.1016/j.fcr.2020.108008

30. Crusciol CAC, Cottica RL, Lima EDV et al (2005) Persistência de palhada e liberação de nutrientes do nabo forrageiro no plantio direto. Pesquisa Agropecuária Brasileira 40:161-168. https://doi.org/10.1590/S0100-204X2005000200009

31. Curtright AJ, Tiemann LK (2021) Intercropping increases soil extracellular enzyme activity: A meta-analysis. Agr Ecosyst Environ 319:107489. https://doi.org/10.1016/j.agee.2021.107489

32. Denardin LGO, Martins AP, Carmona FDC et al (2020) Integrated crop-livestock systems in paddy fields: New strategies for flooded rice nutrition. Agron J 112:2219-2229

33. Denison RF, Harter BL (1995) Nitrate effects on nodule oxygen permeability and leghemoglobin (nodule oximetry and computer modeling). Plant physiology 107:1355-1364. https://doi.org/10.1104/pp.107.4.1355

34. Dhakal D, Islam MA (2018) Grass-legume mixtures for improved soil health in cultivated agroecosystem. Sustainability 10:2718. https://doi.org/10.3390/su10082718

35. Dick RP, Breakwell DP, Turco RF (1997) Soil enzyme activities and biodiversity measurements as integrative microbiological indicators. Methods for assessing soil quality 49:247-271. https://doi.org/10.2136/sssaspecpub49.c15

36. Eivazi F, Tabatabai MA (1988) Glucosidases and galactosidases in soils. Soil Biol Biochem 20:601-606. https://doi.org/10.1016/0038-0717(88)90141-1

37. El Moujahid L, Le Roux X, Michalet S et al (2017) Effect of plant diversity on the diversity of soil organic compounds. PLoS One 12:e0170494. https://doi.org/10.1371/journal.pone.0170494

38. Ellert BH, Bettany JR (1995) Calculation of organic matter and nutrients stored in soils under contrasting management regimes. Can J Soil Sci 75:529-538. https://doi.org/10.4141/cjss95-075

39. Fang Y, Singh BP, Collins D et al (2018) Nutrient supply enhanced wheat residue-carbon mineralization, microbial growth, and microbial carbon-use efficiency when residues were supplied at high rate in contrasting soils. Soil Biol Biochem 126:168-178. https://doi.org/10.1016/j.soilbio.2018.09.003

40. Feng $\mathrm{H}$, Sekaran $\mathrm{U}$, Wang $\mathrm{T}$ et al (2021) On-farm assessment of cover cropping effects on soil $\mathrm{C}$ and $\mathrm{N}$ pools, enzyme activities, and microbial community structure. The Journal of Agricultural Science. https://doi.org/10.1017/S002185962100040X

41. Ferreira EPDB, Stone LF, Martin-Didonet CCG (2017) Population and microbial activity of the soil under an agro-ecological production system. Revista Ciência Agronômica 48:22-31

42. Frasier I, Noellemeyer E, Figuerola E et al (2016) High quality residues from cover crops favor changes in microbial community and enhance $C$ and N sequestration. Global Ecology Conservation 6:242-256. https://doi.org/10.1016/j.gecco.2016.03.009

43. Freddi OS, Tavanti RFR, Soares MB et al (2017) Physical-chemical quality of a Latosol under direct seeding and soybean-corn succession in the Cerrado-Amazonian ecotone. Rev Caatinga 30:991-1000

44. Gazolla PR, Guareschi RF, Perin A et al (2015) Frações da matéria orgânica do solo sob pastagem, sistema plantio direto e integração lavoura-pecuária. Semina: Ciências Agrárias 36:693-704. https://doi.org/10.5433/1679-0359.2015v36n2p693

45. Hartman WH, Richardson CJ (2013) Differential nutrient limitation of soil microbial biomass and metabolic quotients $\left(q \mathrm{CO}_{2}\right)$ : is there a biological stoichiometry of soil microbes? PloS one 8:e57127. https://doi.org/10.1371/journal.pone.0057127

46. Hungria M, Franchini JC, Brandão-Junior O et al (2009) Soil microbial activity and crop sustainability in a long-term experiment with three soil tillage and two crop-rotation systems. Agric Ecosyst Environ Appl Soil Ecol 42:288-296.

https://doi.org/10.1016/j.apsoil.2009.05.005

47. Hurisso TT, Davis JG, Brummer JE et al (2013) Rapid changes in microbial biomass and aggregate size distribution in response to changes in organic matter management in grass pasture. Geoderma 193:68-75.

Page $13 / 18$ 
https://doi.org/10.1016/j.geoderma.2012.10.016

48. Jekinson D, Powlson D (1976) The effect of biocidal treatments on metabolism in soil. Biology Biochemistry 8:209-213. https://doi.org/10.1016/0038-0717(76)90005-5

49. Jenkinson DS, Powlson DS (1976) The effects of biocidal treatments on metabolism in soil-V: a method for measuring soil biomass. Soil biology Biochemistry 8:209-213

50. Lanna AC, Silveira PMD, Silva MBD et al (2010) Atividade de urease no solo com feijoeiro influenciada pela cobertura vegetal e sistemas de plantio. Revista Brasileira de Ciência do Solo 34:1933-1939. https://doi.org/10.1590/S0100-06832010000600018

51. Laroca JVDS, Souza JMAD, Pires GC et al (2018) Soil quality and soybean productivity in crop-livestock integrated system in no-tillage. Pesquisa Agropecuária Brasileira 53:1248-1258. https://doi.org/10.1590/S0100-204X2018001100007

52. Leite LF, Arruda FPD, Costa CDN et al (2013) Qualidade química do solo e dinâmica de carbono sob monocultivo e consórcio de macaúba e pastagem. Revista Brasileira de Engenharia Agrícola e Ambiental 17:1257-1263. https://doi.org/10.1590/S141543662013001200002

53. Li Q, Yu P, Li G, Zhou D (2016) Grass-legume ratio can change soil carbon and nitrogen storage in a temperate steppe grassland. Soil Tillage Res 157:23-31. https://doi.org/10.1016/j.still.2015.08.021

54. Lisboa BB, Vargas LK, Silveira AOD et al (2012) Indicadores microbianos de qualidade do solo em diferentes sistemas de manejo. Revista Brasileira de Ciência do solo 36:33-44. https://doi.org/10.1590/S0100-06832012000100004

55. Lopes AAC, Gomes de Sousa DM, Chaer GM et al (2013) Interpretation of microbial soil indicators as a function of crop yield and organic carbon. Soil Sci Soc Am J 77:461-472. https://doi.org/10.2136/sssaj2012.0191

56. Louarn G, Pereira-Lopès E, Fustec J (2015) The amounts and dynamics of nitrogen transfer to grasses differ in alfalfa and white clover-based grass-legume mixtures as a result of rooting strategies and rhizodeposit quality. Plant Soil 389:289-305. https://doi.org/10.1007/s11104-014-2354-8

57. Luciano RV, Albuquerque JA, Costa A et al (2012) Physical attributes related to soils compaction under native vegetation in a southern Brazil altitude region. Rev Bras Ciênc Solo 36:1733-1744

58. Mader P, Fliessbach A, Dubois D et al (2002) Soil fertility and biodiversity in organic farming. Science 296:1694-1697. http://dx.doi.org/10.1126/science.1071148

59. Martins AP, Denardin LGO, Borin JBM et al (2017) Short-term impacts on soil-quality assessment in alternative land uses of traditional paddy fields in southern Brazil. Land degradation development 28:534-542. https://doi.org/10.1002/ldr.2640

60. Mateus GP, Crusciol CAC, Pariz CM et al (2020) Corn intercropped with tropical perennial grasses as affected by sidedress nitrogen application rates. Nut Cycl Agroecosyst. https://doi.org/10.1007/s10705-019-10040-1

61. Mead R, Willey R (1980) The concept of a 'land equivalent ratio' and advantages in yields from intercropping. Exp Agric 16:217228. https://doi.org/10.1017/S0014479700010978

62. Moraes A, Carvalho PCF, Crusciol CAC et al (2019b) Integrated crop-livestock systems as a solution facing the destruction of pampa and cerrado biomes in South America by intensive monoculture systems. Agroecosyst Divers. https://doi.org/10.1016/B978-0-12-811050-8.00016-9

63. Moraes JMAS, Zanchi CS, Pires GC et al (2019a) Arbuscular mycorrhizal fungi in integrated crop livestock systems with intercropping in the pasture phase in the Cerrado. Rhizosphere 11:100165. https://doi.org/10.1016/j.rhisph.2019.100165

64. Mott GO, Lucas HL (1952) The design conduct and interpretation of grazing trials on cultivated and improved pastures. In: International Grassland Congress, 6, 1952, Pensylvania. Poceedings... State College, Pensylvania, pp 1380-1395

65. Mwakilili AD, Mwaikono KS, Herrera SL et al (2021) Long-term maize-Desmodium intercropping shifts structure and composition of soil microbiome with stronger impact on fungal communities. Plant Soil. https://doi.org/10.1007/s11104-02105082-w

66. Nascente AS, Stone LF (2018) Cover crops as affecting soil chemical and physical properties and development of upland rice and soybean cultivated in rotation. Rice Sci 25:340-349. https://doi.org/10.1016/j.rsci.2018.10.004

67. Nunes MR, van Es HM, Schindelbeck R et al (2018) No-till and cropping system diversification improve soil health and crop yield. Geoderma 328:30-43. https://doi.org/10.1016/j.geoderma.2018.04.031

68. Nunes RDS, Castro Lopes AAD, Sousa DMGD et al (2011) Sistemas de manejo e os estoques de carbono e nitrogênio em latossolo de cerrado com a sucessão soja-milho. Revista Brasileira de Ciência do Solo 35:1407-1419

Page $14 / 18$ 
69. Pacheco LP, Miguel ASDCS, Silva RGD et al (2017) Biomass yield in production systems of soybean sown in succession to annual crops and cover crops. Pesquisa Agropecuária Brasileira 52:582-591. https://doi.org/10.1590/S0100-

204X2017000800003

70. Pires GC, Lima ME, Zanchi CS et al (2021) Arbuscular mycorrhizal fungi in the rhizosphere of soybean in integrated crop livestock systems with intercropping in the pasture phase. Rhizosphere 17:100270. https://doi.org/10.1016/j.rhisph.2020.100270

71. Preisner EC, Fichot EB, Norman RS (2016) Microbial mat compositional and functional sensitivity to environmental disturbance. Frontiers in microbiology 7:1632. https://doi.org/10.3389/fmicb.2016.01632

72. Reis JC, Rodrigues GS, Barros I et al (2021) Integrated crop-livestock systems: A sustainable land-use alternative for food production in the Brazilian Cerrado and Amazon. J Clean Prod 283:124580. https://doi.org/10.1016/j.jclepro.2020.124580

73. Rocha KF, Souza M, Almeida DS et al (2020) Cover crops affect the partial nitrogen balance in a maize-forage cropping system. Geoderma 360:114000. https://doi.org/10.1016/j.geoderma.2019.114000

74. Salinas-Garcia JR, Velázquez-Garcıá JJ, Gallardo-Valdez M et al (2002) Tillage effects on microbial biomass and nutrient distribution in soils under rain-fed corn production in central-western Mexico. Soil Tillage Res 66:143-152. https://doi.org/10.1016/S0167-1987(02)00022-3

75. Salton JC, Mercante FM, Tomazi M et al (2014) Integrated crop-livestock system in tropical Brazil: Toward a sustainable production system. Agr Ecosyst Environ 190:70-79. https://doi.org/10.1016/j.agee.2013.09.023

76. Sant-Anna SA, Jantalia CP, Sa JM et al (2017) Changes in soil organic carbon during 22 years of pastures, cropping or integrated crop/livestock systems in the Brazilian Cerrado. Nutr Cycl Agroecosyst 108:101-120. https://doi.org/10.1007/s10705-016-9812-z

77. Sarto MV, Borges WL, Sarto JR et al (2020) Deep soil carbon stock, origin, and root interaction in a tropical integrated croplivestock system. Agrofor Syst 94:1865-1877. https://doi.org/10.1007/s10457-020-00505-6

78. Schipanski ME, Drinkwater LE (2012) Nitrogen fixation in annual and perennial legume-grass mixtures across a fertility gradient. Plant Soil 357:147-159. https://doi.org/10.1007/s11104-012-1137-3

79. Sekaran U, Sagar KL, Denardin LGO et al (2020) Responses of soil biochemical properties and microbial community structure to short and long-term no-till systems. Eur J Soil Sci 71:1018-1033. https://doi.org/10.1111/ejss.12924

80. Silva RRD, Silva MLN, Cardoso EL et al (2010) Biomassa e atividade microbiana em solo sob diferentes sistemas de manejo na região fisiográfica Campos das Vertentes-MG. Revista Brasileira de Ciência do Solo 34:1584-1592. https://doi.org/10.1590/S0100-06832010000500011

81. Soares MB, Freddi ODS, Matos EDS et al (2020) Integrated production systems: An alternative to soil chemical quality restoration in the Cerrado-Amazon ecotone. Catena 185:104279. https://doi.org/10.1016/j.catena.2019.104279

82. Soil Survey Staff (2000) Keys to soil taxonomy: Blacksburg, Virginia. Pocahontas Press, $600 \mathrm{p}$

83. Sparling GP (1992) Ratio of microbial biomass carbon to soil organic carbon as a sensitive indicator of changes in soil organic matter. Soil Research 30:195-207. https://doi.org/10.1071/SR9920195

84. Spohn M (2015) Microbial respiration per unit microbial biomass depends on litter layer carbon-to-nitrogen ratio. Biogeosciences 12:817-823. https://doi.org/10.5194/bg-12-817-2015

85. Stieven AC, Oliveira DA, Santos JO et al (2014) Impacts of integrated crop-livestock-forest on microbiological indicators of soil. Revista Brasileira de Ciências Agrárias 9:53-58. https://doi.org/10.5039/agraria.v9i1a3525

86. Tabatabai MA (1994) Soil enzymes. In: Weaver RW, Angle JS, Bottomley PS (eds) Methods of soil analysis, part 2. Microbiological and biochemical properties. E-Publishing Inc., Madison: Soil Science Society of America Journal, pp 775-833

87. Tabatabai MA, Bremner JM (1972) Assay of urease activity in soils. Soil Biol Biochem 4:479-487

88. Tanaka RT, Mascarenhas HAA, Dias OS et al (1992) Cultivo da soja após incorporação de adubo verde e orgânico. Pesquisa Agropecuária Brasileira 27:1477-1483

89. Tate KR, Ross DJ, Feltham CW (1988) A direct extraction method to estimate soil microbial C: effects of experimental variables and some different calibration procedures. Soil Biol Biochem 20:329-335. https://doi.org/10.1016/0038-0717(88)90013-2

90. Tavanti RFR, Silva FO, Marchioro V et al (2019) Least limiting water as a soil indicator in an integrated crop-livestock systems of the Cerrado, Brazil. Geoderma regional 19:e00232

Page 15/18 
91. Tedesco MJ, Gianello C, Bissani CA et al (1995) Análises de solo, plantas e outros materiais (Vol, 5. Ufrgs, Porto Alegre, p 174

92. Vance ED, Brookes PC, Jenkinson DS (1987) An extraction method for measuring soil microbial biomass C. Soil biology Biochemistry 19:703-707. https://doi.org/10.1016/0038-0717(87)90052-6

93. Veloso MG, Dick DP, Costa JB, Bayer C (2019) Cropping systems including legume cover crops favour mineral-organic associations enriched with microbial metabolites in no-till soil. Soil Research 57:851-858. https://doi.org/10.1071/SR19144

94. Verstraete W, Voets JP (1977) Soil microbial and biochemical characteristics in relation to soil management and fertility. Soil Biol Biochem 9:253-258. https://doi.org/10.1016/0038-0717(77)90031-1

95. Wardle DA, Ghani A (1995) A critique of the microbial metabolic quotient (qCO2) as a bioindicator of disturbance and ecosystem development. Soil Biol Biochem 27:1601-1610

96. Ye D, Li T, Zhang X, Zheng Z, Dai W (2017) Rhizosphere P composition, phosphatase and phytase activities of Polygonum hydropiper grown in excess $P$ soils. Biol Fertil Soils 53:823-836. https://doi.org/10.1007/s00374-017-1218-9

97. Zhao J, Zeng Z, He X et al (2015) Effects of monoculture and mixed culture of grass and legume forage species on soil microbial community structure under different levels of nitrogen fertilization. European Journal of Soil Biology 68:61-68. https://doi.org/10.1016/j.ejsobi.2015.03.008

\section{Figures}
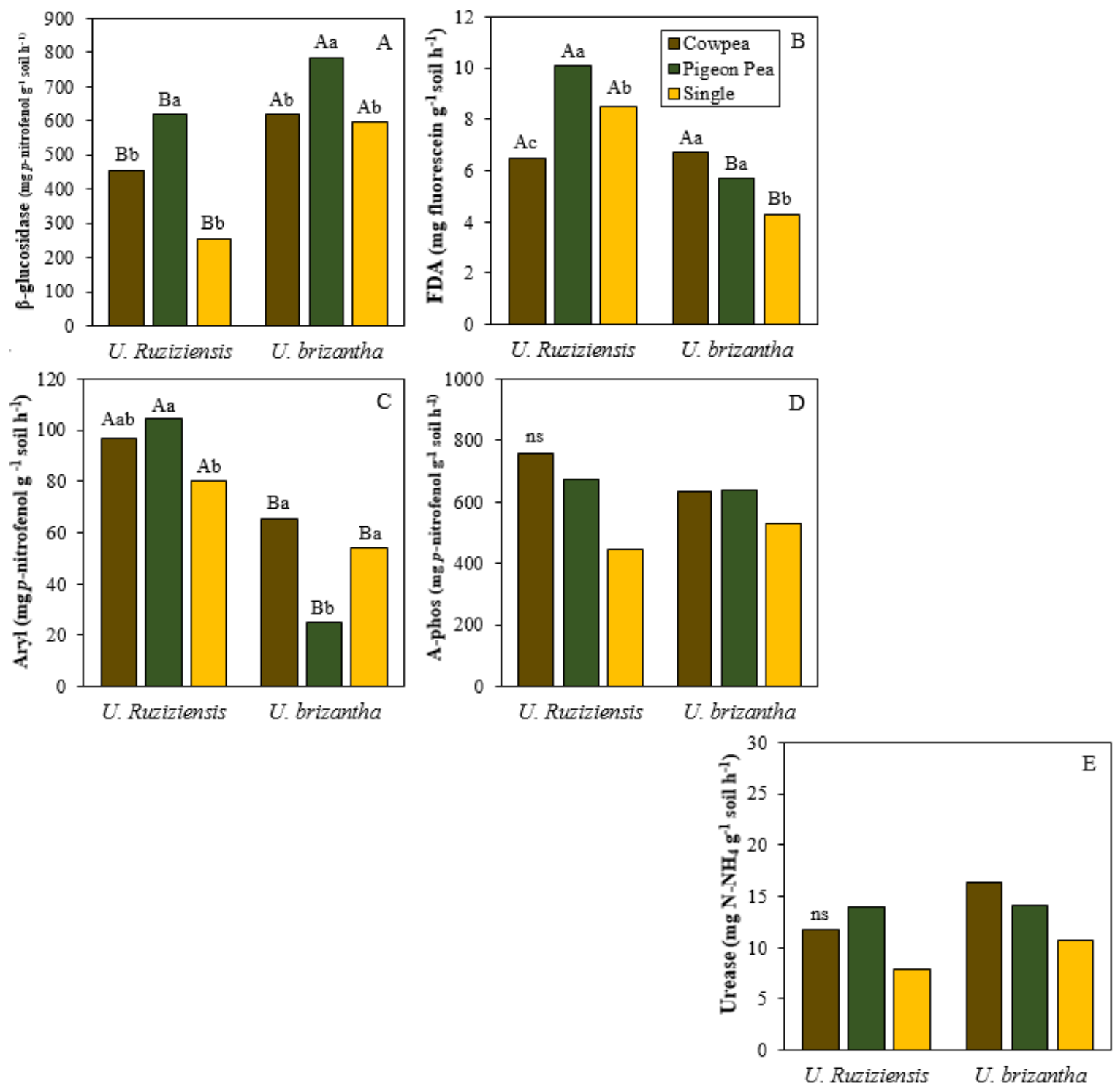

Figure 1 
$\beta$-glucosidase (A), fluorescein diacetate (FDA) (B), arylsulfatase (Aryl) (C), acid phosphatase (A-phos) (D), and urease (E) activity two years after the adoption (March 2018) of an integrated crop-livestock system under no-tillage and different grasses and legumes intercrops at the pasture stage. Tukey's test $(p<0.05)=$ Uppercase letters indicate differences between grasses. Lowercase letters indicate differences among intercropping. $\mathrm{ns}=$ not significant.

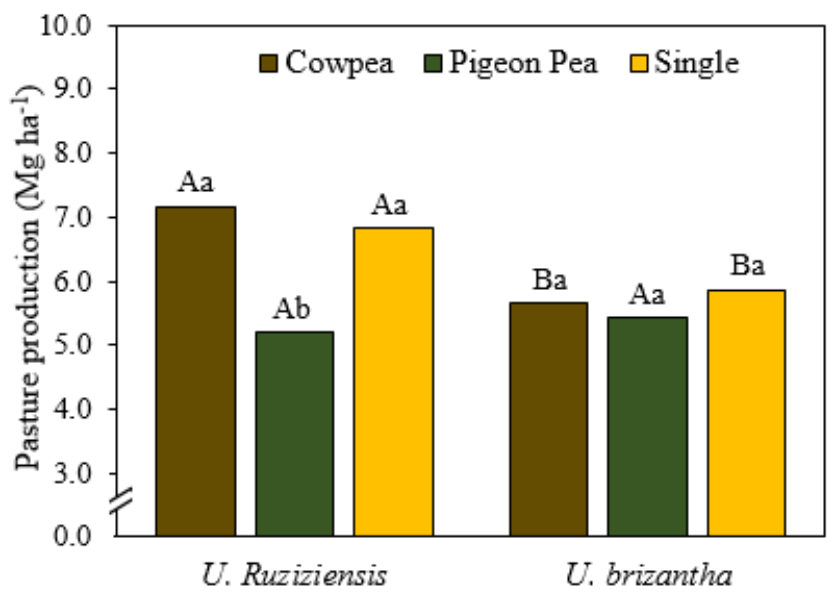

\section{Figure 2}

Pasture shoot biomass before the start of grazing in an integrated crop-livestock system under no-tillage and different grass-legume intercropping at the pasture stage on average of 2016 and 2017 growing seasons. Tukey's test $(p<0.05)=$ Uppercase letters indicate differences between grasses. Lowercase letters indicate differences among intercropping.
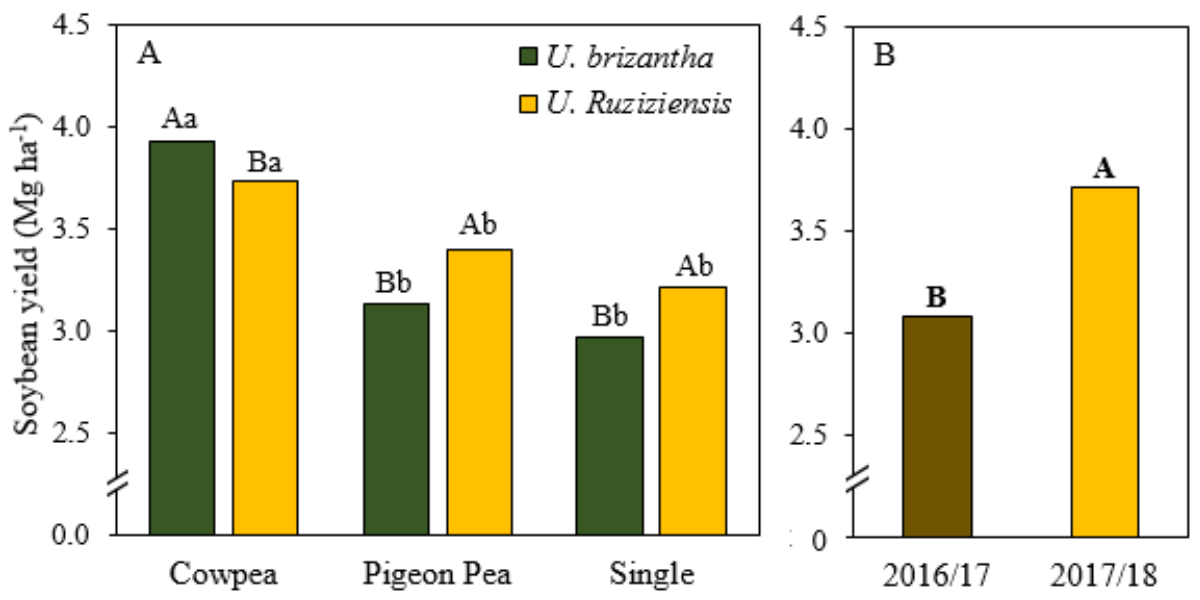

\section{Figure 3}

Soybean yield in an integrated crop-livestock system under no-tillage and different grasses and legumes intercrops at the pasture stage (A) in 2016/17 and 2017/18 cropping seasons (B). Tukey's test $(p<0.05)=$ Uppercase letters indicate differences between grasses or cropping seasons. Lowercase letters indicate differences among intercropping. 


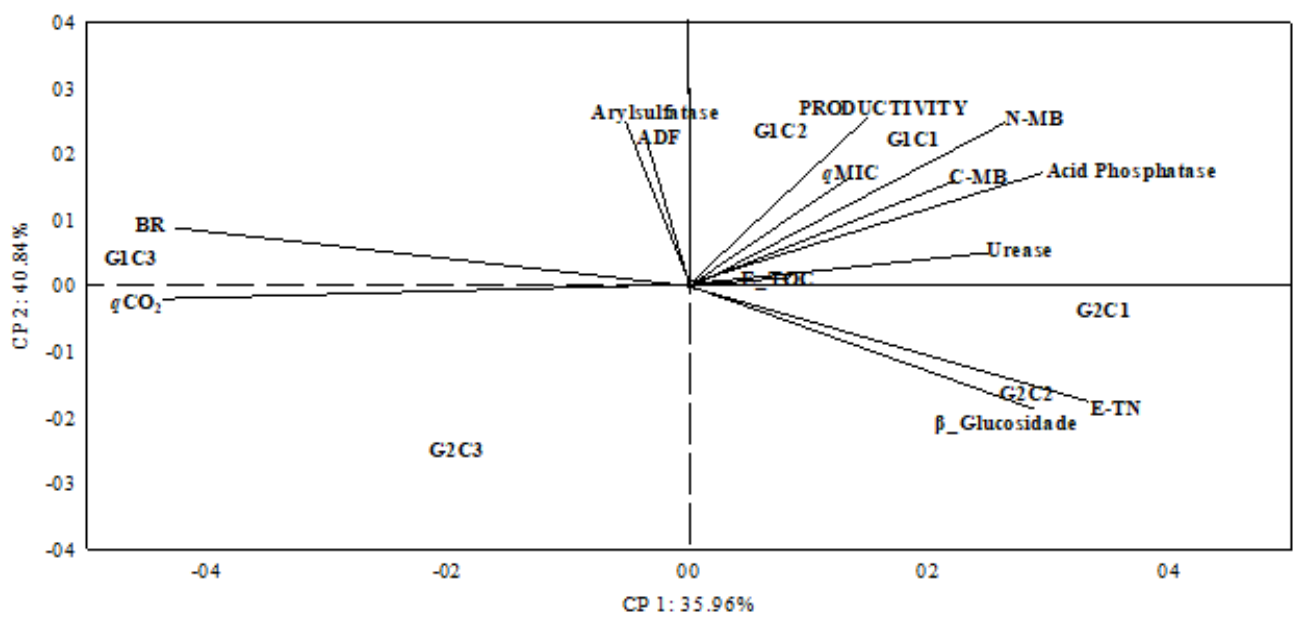

Figure 4

Graphical distribution of soil biochemical properties and soybean yield according to their similarities in an integrated crop-livestock system under no-tillage with intercrops at the pasture stage. G1C1: U. Ruziziensis intercropped with Cowpea; G1C2: U. Ruziziensis intercropped with Pigeon pea; G1C3: U. Ruziziensis single; G2C1: U. brizantha intercropped with Cowpea; G2C2: U. brizantha intercropped with Pigeon pea; G2C3: U. brizantha single.

\section{Supplementary Files}

This is a list of supplementary files associated with this preprint. Click to download.

- SupplementaryFig.docx 